\title{
Patterns and Trends of Crocodile Trade from Tanah Papua, Indonesia
}

\author{
Dewi Untari ${ }^{1,}{ }^{,}$, Hardjanto Hardjanto ${ }^{1}$, Bramasto Nugroho ${ }^{1}$, Rinekso Soekmadi \\ 1 IPB Unversity \\ * Corresponding author: untaridewi@gmail.com
}

\begin{abstract}
Crocodylus porosus and C. novaeguineae are two protected and tradable crocodile species in Indonesia. Therefore, precautionary principles are needed in their utilization to ensure sustainability. Although the commodity from these species is traded domestically and internationally, the broader picture of its use in Indonesia is less known. The objectives of the study were to: (1) analyze the domestic trade of crocodiles, and (2) analyze the international trade of crocodiles. The analysis was conducted using data of direct utilization sourced from the wild in the form of skin and hatchlings, data on domestic transport permits, CITES export permits, and the CITES trade database. The study suggested that the harvest of crocodile hatchlings and skin do not represent the actual condition since the skin recorded were only those sent outside of the province. Determining zero harvest quotas of $C$. porosus did not stop species harvest for domestic trade. The dominant source of $C$. porosus skin export was captive breeding, while $C$. novaeguineae was sourced from the wild. Ranch-sourced skin of both species for export were very low.
\end{abstract}

Keywords: CITES; harvest quota; Irian fresh water crocodile; saltwater crocodile; wildlife trade

\section{Introduction}

Wildlife trade is one of the main contributors to the loss of biodiversity (Grieser Johns \& Thompson, 2005; Sutherland et al., 2009). Wildlife utilization for trade is often done by overexploiting the resources, which threatens its availability in the future (Pires \& Moreto, 2011), whether it is a population decline or extinction in the wild.

The Irian Freshwater crocodile (Crocodylus novaeguineae, Schmidt 1928) and the saltwater crocodile (Crocodylus porosus, Schneider 1801) are two crocodile species in Indonesia being traded internationally. C. porosus and C. novaeguineae are listed in Appendix II Convention on International Trade in Endangered Species of Wild Fauna and Flora (CITES) and are protected wildlife in Indonesia (KLHK, 2018; Sekretariat Negara, 1999). To maintain the sustainability of C. porosus and C. novaeguineae, the government of Indonesia established various regulations (Pires \& Moreto, 2011) to control its trade. The arrangements based on the regulation were: 1 ) regulating that crocodile utilization sourced from the wild are only allowed in Tanah Papua (Papua and West Papua Provinces) based on the Minister of Forestry Decree Number 2827/Kpts-II/2002 concerning establishment of saltwater crocodiles (C. porosus) and fresh water Irian crocodile ( $C$. novaeguineae) as hunting animals in Papua and West Papua Province; 2 ) controlling utilization from the wild by arranging harvest quotas through the Minister of Forestry Decree Number 447/Kpts-II/2003 concerning the Trade of Wild Flora and Fauna Collection or Hunting and Distribution; and 3) utilization from ranching and captive breeding to reduce the utilization sourced from the wild through the Minister of Forestry Decree Number P.19/Menhut-II/2005 concerning Wild Flora and Fauna Captive Breeding as amended by Minister of Forestry Regulation Number P.69/MenhutII/2013.

Regulations were meant to reduce the dependency of crocodile utilization from the wild through ranching and captive breeding. To understand the utilization from the wild, ranching, and captive breeding, analysis on domestic and international trade of the two species is required.

Many analyses already exist on the legal international trade under the CITES framework, whether comprehensive analysis of all CITES databases (Harfoot et al., 2018), or by taxonomic group: amphibians (Carpenter et al., 2014) and reptiles (Auliya et al., 2016; Robinson et al., 2015); or at a species level: Vicugna vicugna (Mcallister et al., 2009), on leopards (D'Cruze \& Macdonald, 
2015), and on crocodiles (Caldwell, 2015; Caldwell, 2017). The same is true with international trade, in which there were also analyses on wildlife trade in Indonesia, such as for mammals, reptiles and amphibians (Janssen \& Chng, 2017), reptiles (Nijman \& Shepherd, 2009; Nijman, 2010; Nijman et al., 2012), reticulated python (Natusch et al., 2016; Nurmalasari et al., 2016), Ptyas mucosa (Auliya, 2010), green pythons (Lyons \& Natusch, 2011), and crocodiles (Kurniati, 2016; Kurniati et al., 2017). The previous analysis of crocodile trade sourced from the wild and ranching in Indonesia (Kurniati, 2016; Kurniati et al., 2017) has not yet provided the picture of distribution flow, origin (UNCTAD, 2014; Yao and Zhu, 2019), and the trend in crocodile trade (Caldwell, 2015; Caldwell, 2017). To better understand whether species trade could still support its sustainability in the wild, we need to understand the pattern and trend of crocodile trade along with the factors influencing it, such as policy formulation (Cubbage et al., 2006; Fischer et al., 2007) and supply (Harfoot et al., 2018).

Based on the above-mentioned background and issues, a study is needed to: (1) analyze the domestic trade of crocodiles, and (2) analyze the international trade of crocodiles.

\section{Methods}

\subsection{Study area}

Data collection in this study was conducted in two provinces in Tanah Papua: Papua and West Papua (Figure 1), because harvesting wild crocodiles is permitted only in Tanah Papua.

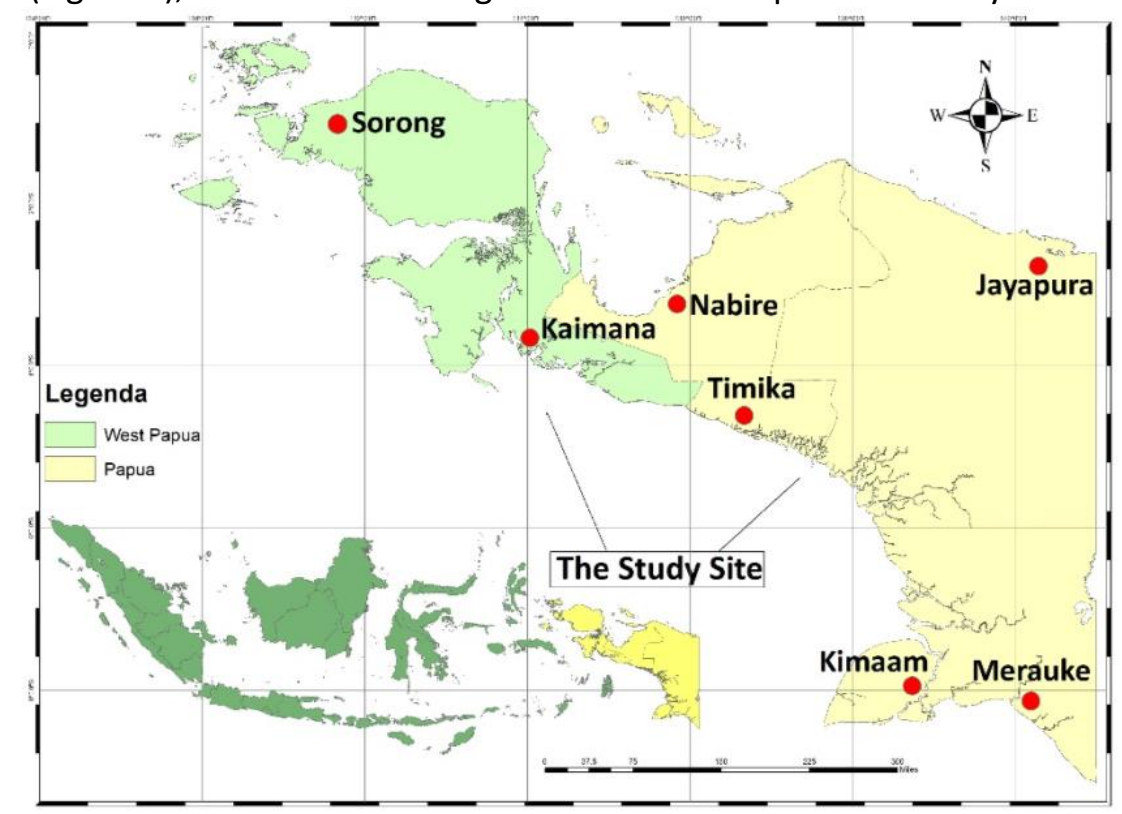

Figure 1. Map of the study site

The data was collected through interview with to the following respondents: 1) traditional hunters and small collectors from Kumbis and Komolom Villages, Kimaam Subdistrict, Merauke District, Papua Province; 2 ) the holders of hunting permit and domestic-distributor permit in Papua and West Papua; 3 ) rancher permit holders in Jayapura, Nabire, Sorong, and Kaimana; 4) exporter permit holders in Papua and West Papua; 5) crocodile skin craftsmen in Merauke, Jayapura, and Timika; and 6) Natural Resources Conservation Office (NRCO) officers.

\subsection{Data collection}

The analysis on crocodile trade in Indonesia was conducted using the data of direct utilization sourced from the wild in the form of skin and hatchlings, the data on domestic transport permit 
establishment, Indonesia export database which was based on the establishment of CITES export permit, and CITES trade database (https://www.trade.cites.org).

The domestic transport permit analyzed were those established for harvest permit holders. The documents were established for commercial purposes. There were 198 documents of domestic transport permit data analyzed from 2014 - 2017. The sending origins were from Papua, West Papua, Jakarta, Yogyakarta, and Bali.

The same also applied for export permit where the ones analyzed in Indonesian export and CITES database were those categorized for commercial purposes. In the CITES categorization of purpose, the symbol for commercial or trade is T (Robinson and Sinovas, 2018). There were 1,655 data of export permit from 2010 - 2017. However, 255 export permits were not realized, and thus the export realization was 1,400 .

\subsection{Data analysis}

The domestic trade was analyzed using the following data: (1) crocodile hunting in Tanah Papua, and (2) domestic transport permit from several NRCO that receive the flow of crocodile skin or hatchlings. The domestic transport permit data analyzed from Tanah Papua were the shipping destination, and traced down from its origin to its next destination, and so on. The data were then traced down to the export point, which is the establishment of export permit.

We used harvest realization (with data from NRCO) and compared it with quota to see the pattern and trend of crocodile harvest in Tanah Papua. The realization and quota were categorized based on the species, then we categorized hatchlings and adults. Hatchlings went to ranching while adults were taken for its skin. Next, the patterns and trend of harvest for both species were compared to the factual harvest in the field by using the data reported by crocodile skin craftsmen (unpublished) and based on the interviews with hunters; collectors; the holders of hunting permit, domestic distribution permit, rancher permit, exporter permit; and NRCO officers.

The same thing was done with international trade, which was traced down from the export permit in the export database available at the Directorate of Biodiversity Conservation. This database is used by the management authority in fulfilling their obligation to provide an annual report on wildlife trade to the CITES Secretariat. The database includes license, transaction type (export, import, re-export), category of wildlife, trader, partner, destination, remarks, purpose, issued, name (scientific, English, local), source (wild, ranching, captive), quota, quantity, realization, exported, measurement, and description.

The export permit consists of 1) export sourced from the wild, ranching, and captive breeding, 2) import, and 3) re-export. Destination countries were also classified to see the pattern and trend of export trade. Each species was analyzed to see the export trend within 2010-2017 period. We then classified the data based on its source (wild, ranching, captive) to see if there were any shifts in the export trade.

Next, CITES trade database from https://www.trade.cites.org was used to get information of the position of $C$. porosus' and $C$. novaeguineae's trade from Indonesia in the international crocodile market. To observe the pattern and trend of the two species in the global crocodile trade, we classified both species data and all data of Crocodylia order and compared it. The pattern and trend of $C$. porosus trade was obtained by separating the ones originating from Indonesia with the ones from other countries (Malaysia, Philippines, Singapore, Thailand, and Bangladesh, Australia, and Papua New Guinea). The same was done for $C$. novaeguineae, where we separated the data based on the country of origin (Indonesia and Papua New Guinea).

The number of individuals traded was calculated based on the number of skin. Skin is the primary commodity of a crocodile, and therefore the skin is counted as an individual. Other products such as meat, back croc bone, oil, and crocodile's genitals were not counted as separate individuals. 
Those commodities were considered as wastes of crocodile skin and would cause duplication if they were counted.

\section{Results}

\subsection{Domestic Trade}

\subsubsection{The harvested crocodile taken from the wild or the harvested crocodile}

Based on Minister of Forestry Decree Number 2827/Kpts-II/2002, the government has decided $C$. porosus and $C$. novaeguineae as hunting animals applied exclusively in Tanah Papua. Based on the decree, the hunting zone in Tanah Papua is divided into three zones, which are Memberamo Zone, Bird's Head Zone, and Merauke Zone (Figure 2). The appointment of these hunting zones was set in advance by the Director-General of Forest Protection and Nature Preservation Decree Number 93/Kpts/DJ-VI/96.

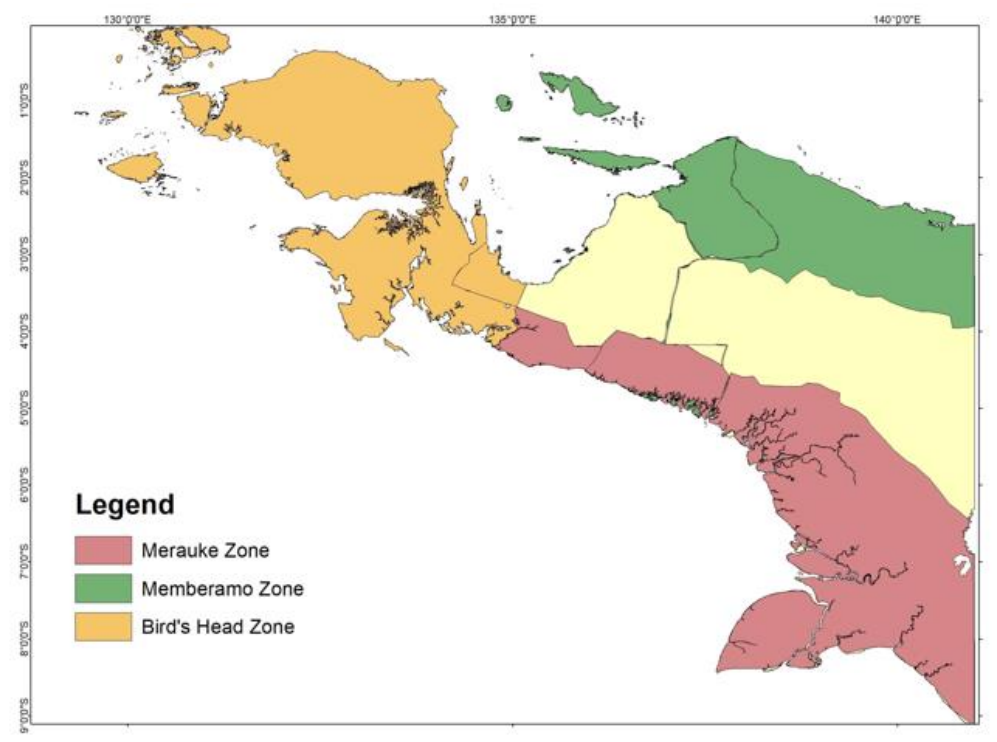

Figure 2. The crocodile hunting zones

The Memberamo Zone spread from the middle up to the north of Papua province (Figure 2). It is the habitat of $C$. novaeguineae (Kurniati, 2002; Cox, 2010; BBKSDA Papua, 2015a; BBKSDA Papua, 2016; Solmu and Monalis, 2019), but based on the population monitoring survey in 2016, $C$. porosus was also found in the upstream and middle stream area (BBKSDA Papua, 2016). The Merauke Zone is dominated by C. porosus (BBKSDA Papua, 2015b; BBKSDA Papua, 2017; Crocodile Specialist Group, 1996; Kurniati et al., 1999; Kurniati, 2016; Webb et al., 2010;; ) and spread in the southern part of Papua province (Figure 2). The Bird's Head Zone is also dominated by $C$. porosus (BBKSDA Papua Barat, 2015; Crocodile Specialist Group, 1996; Kurniati, 1999; Webb et al., 2010;) and covers all areas of West Papua Province (Figure 2).

Crocodile trade control is conducted by setting a harvest quota, which is the maximum limit of crocodile and crocodile hatchlings that can be caught in the wild. The quota is set for domestic and international trade (Departemen Kehutanan, 2003). The percentage of quota for domestic and international trade is not set in the regulations.

The number of hunting of $C$. novaeguineae for its direct utilization in the form of skin in Tanah Papua is relatively high and stable, despite the declining realization (Figure $3 \mathrm{a}$ and b). Differ from its relative's quota, the Scientific Authority gives zero quota recommendation for the harvest of $C$. 
porosus since 2005 (Kurniati, 2016) to prevent the hunting of adult crocodile and encourage captive breeding or ranching. The hunting of $C$. porosus is only allowed for ranching. However, the Management Authority set a harvest quota for C. porosus in 2013 and 2014 (Figure $3 \mathrm{c}$ and d). There was no realization in 2013, while in 2014, the realization was $100 \%$ in Papua and zero in West Papua.
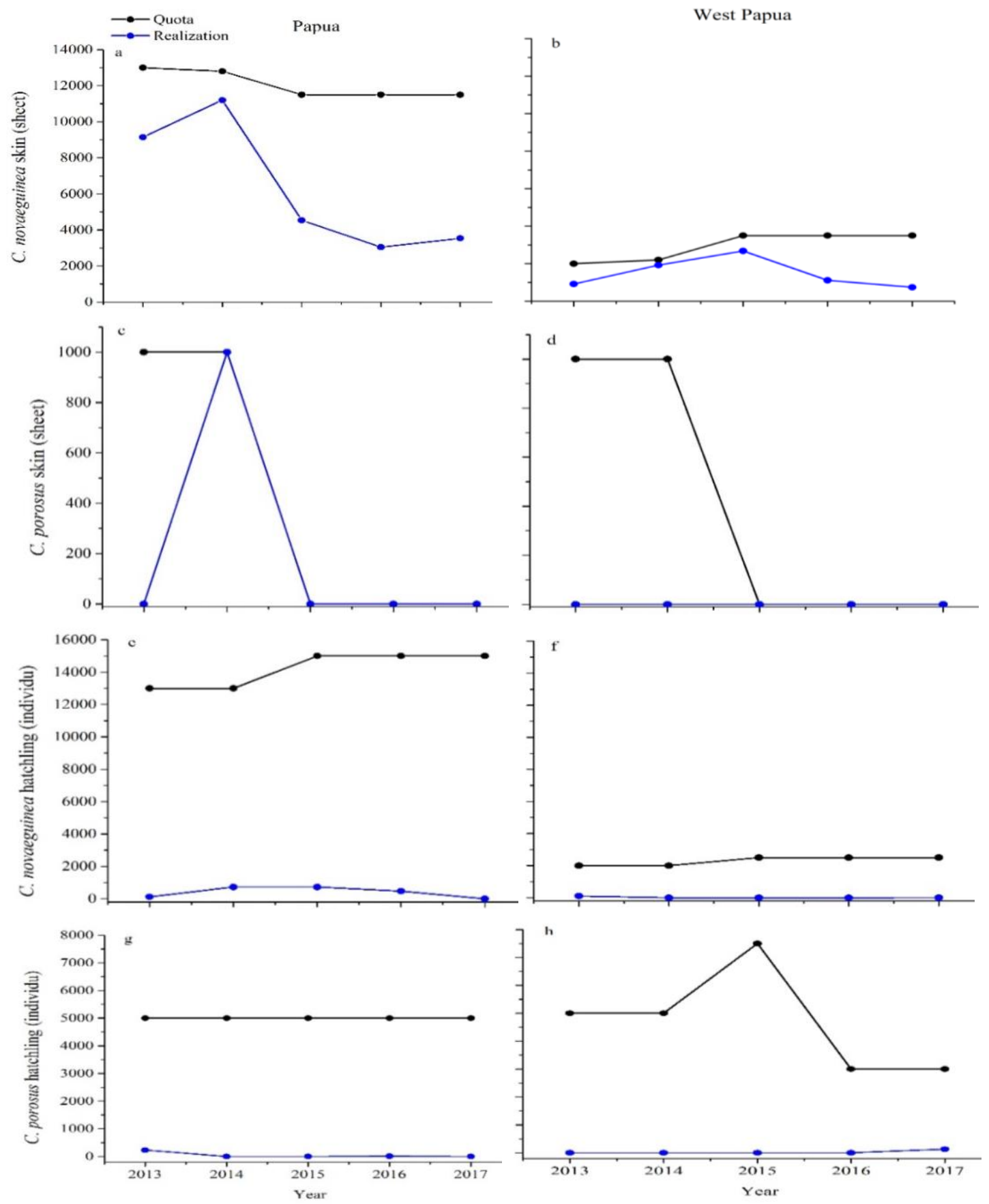

Figure 3. The number of quota and realization of crocodile hunting in Papua and West Papua from $2013-2017$

The quota set for $C$. novaeguineae hatchlings is very high and even increased in 2015 despite its low and declining realization. In West Papua, the realization was very low, as low as 100 individuals in 2013, 8 individuals in 2017, and zero from $2014-2016$. The realization in Papua is higher than West Papua, but in 2017 it had zero realization (Figure 3 e and f). 
The realization for $C$. porosus' hatchlings was very low both in Papua and West Papua (Figure 3 $\mathrm{g}$ and $\mathrm{h}$ ). The realization in West Papua from 2013 - 2016 was zero, and in 2017 it increased to 131 individuals. While in Papua, the realization in 2014, 2015, and 2017 were zero, but the quota set was very high. The realization for C. novaeguineae's hatchlings in 5 years period (2013 - 2017) nationally was 2,154 individuals (Figure 3 e and f). Different from $C$. novaeguineae, the realization for $C$. porosus is very low. During the five years, the realization was only 371 individuals.

Other than for export, the skin sourced from the wild was also used for domestic needs. The local craftsmen in Papua utilized the crocodile skin for the domestic market. The crafts they made, among others, are wallets, belts, shoes, bags, and key chains.

Crocodile skin craftsmen in Merauke are members of the People's Crafts Industry Cooperative named Animha. The raw materials - the crocodile skin was collected from Boven Digoel district (Asiki), Mappi district (Bade), and Merauke district (Kimaam, Muting, Sota, Okaba, Wanam, and Bupul/Elikobel). The skin was obtained from the collectors or directly from hunters that sell in small numbers. The craftsmen in Timika got their raw materials from Mimika district (Otakwa/Far East Mimika and Kokonao/West Mimika) and Memberamo Raya district (Dabra/Memberamo Hulu, and Trimuris/Memberamo Hilir).

Initially, the craftsmen could freely utilize crocodile without any arrangements on the number and species since the Papuans have done it for generations. However, since 2014, The Papua NRCO introduced the regulation for crocodile utilization to the craftsmen so they would obtain skins that are legally sourced. At first, the regulation was only introduced to the craftsmen in Merauke through the Head of Papua NRCO Decree Number SK. 83/IV-15/Tek/2014, dated November 10, 2014. The decree stipulated that the NRCO grant the permit to the local crocodile skin crafts industry in Merauke District to source $C$. novaeguineae and $C$. porosus skin for their industry's raw materials.

The arrangement was then expanded to the craftsmen in Merauke, Timika, and Jayapura districts, and Jayapura city through the Head of Papua NRCO Decree Number SK. 43/IV-15/Tek/2015 on May 29, 2015. Based on the regulation, the local crocodile skin crafts industry in Merauke, Timika, and Japapura districts and Jayapura city are given the permit receive raw material supply for their activities, which is the skin of $C$. novaeguineae and $C$. porosus.

These regulations implied a limitation in crocodile skin utilization in terms of numbers and species. The amount and species that can be utilized for crafts material can be seen in Table 1.

Table 1. The quota for crocodile skin sourced from the wild for craftsmen in Papua from $2015-2017$

\begin{tabular}{rrrrr}
\hline \multirow{2}{*}{ Year } & \multicolumn{2}{c}{ C. porosus } & \multicolumn{2}{c}{ C. novaeguineae } \\
\cline { 2 - 5 } & \multicolumn{1}{c}{ Quota } & Realization & Quota & Realization \\
\hline 2015 & 3782 & - & 1780 & 250 \\
2016 & - & - & 4565 & - \\
2017 & - & - & 3750 & - \\
\hline
\end{tabular}

The utilization of crocodile skin by craftsmen in 2016 and 2017 was not reported as the realization of skin sourced from the wild since there was no record of shipping using domestic transport permit. The skin utilized by craftsmen in Merauke, Jayapura, and Timika came from around the area and was not an interprovincial distribution. Thus it did not require the domestic transport permit document. However, it was recorded that the realization for $C$. novaeguineae's skin sourced from the wild in 2015 was 250 (Table 1).

In 2014 and 2015, craftsmen still received quotas for $C$. porosus and $C$. novaeguineae, but in 2016 and 2017, they only received the quota for $C$. novaeguineae. The quota did not hinder the craftsmen from utilizing the skin of $C$. porosus. As seen in 2017, when the craftsmen in Merauke still utilized $C$. porosus with the composition of $25 \%$ use of $C$. porosus skin and $75 \%$ of $C$. novaeguineae skin in their products (Source: craftsmen monthly reporting data, not published). 


\subsubsection{Crocodile Distribution}

Crocodile can only be traded by the holders of domestic distributor license (Departemen Kehutanan, 2003). Therefore, they are the ones who can distribute crocodile skin within or between provinces in Tanah Papua and outside of Tanah Papua.

Legal domestic distribution of crocodile can be monitored from the domestic transport permit because all crocodile distribution must have domestic transport permit (Departemen Kehutanan, 2003). The domestic transport permit is issued by the head of NRCO or the officials of NRCO according to its authority. Crocodile distribution in all areas of Indonesia is supposed to be able to be monitored from domestic transport permit data, but the data between NRCO are not yet integrated. Therefore, to have a complete figure of crocodile distribution, partial domestic transport permit data from each NRCO must be collected, both the issuing office and the receiving office. The domestic transport permit issued always have a record in the issuing office, but not all office take a record of the domestic transport permit received. Crocodile distribution from Tanah Papua to other regions in Indonesia can be seen in Figure 4.
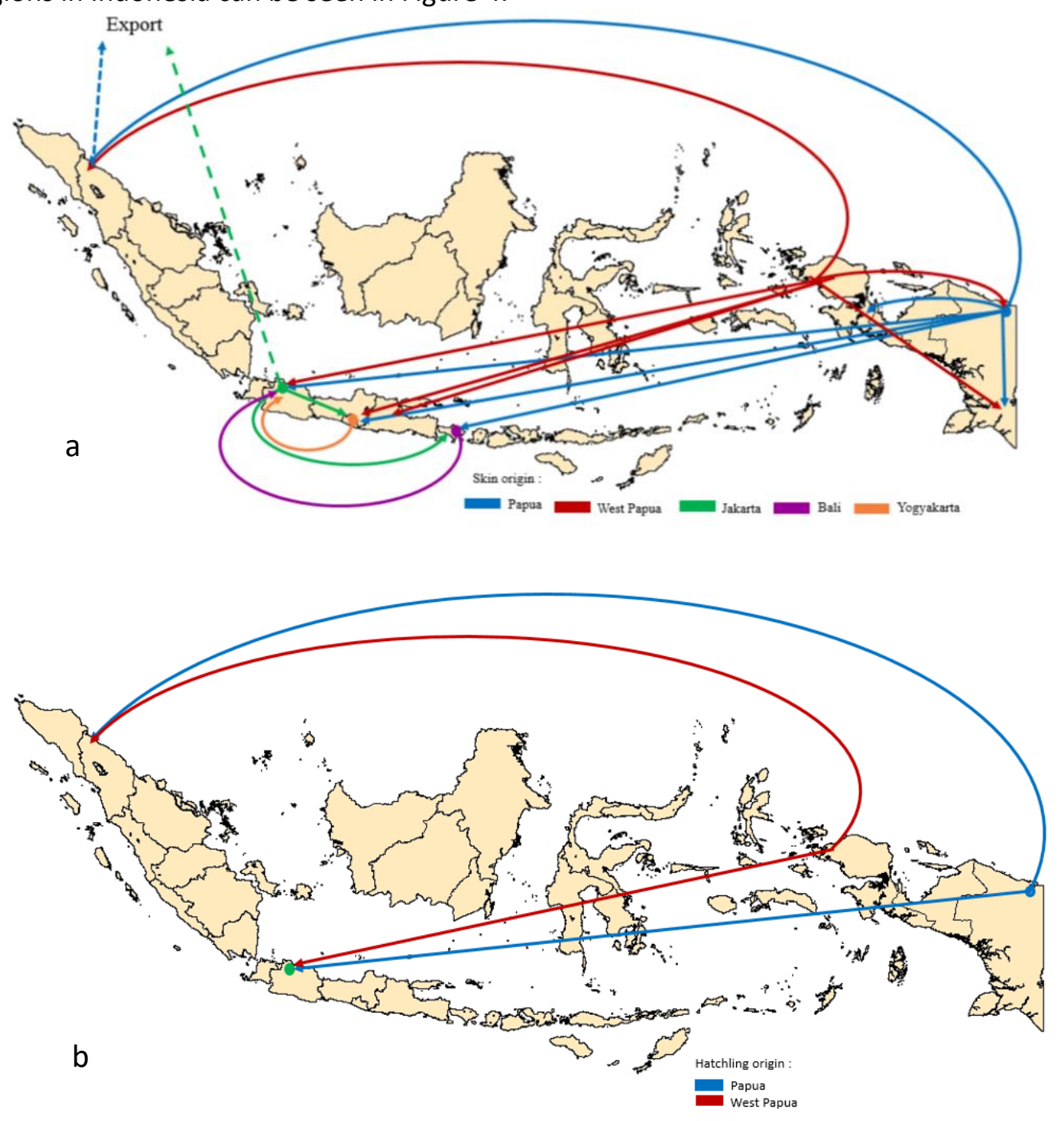

Figure 4. The map of crocodile skin (a) and hatchlings (b) distribution sourced from the wild in Indonesia

Big collectors distributed crocodile skin and hatchlings from Tanah Papua to other regions in Indonesia by using the airplane as its mean of transportation. The skin was distributed to Jakarta, 
Medan, Bali, Yogyakarta, and Kaimana. The skin was also distributed within Papua, from Jayapura to the craftsmen in Merauke. The distribution to Jakarta, Medan, and Bali was for the exporters, to Yogyakarta was for the tanners, and to Kaimana was for the big collectors (Figure 4a).

The big collectors in West Papua distributed crocodile skin sourced from the wild to Jakarta, Medan, and Surabaya. In addition, it was also distributed to the craftsmen in Jayapura and Merauke. The distribution to Jakarta and Medan were for the exporters, while the ones that went to Surabaya was for the tanners in Magetan district.

The distribution of crocodile hatchlings sourced from the wild also used airplanes for transportation. However, the destination was not as varied as it was for the skin. The hatchlings from Tanah Papua were sent only to the ranchers in Medan and Jakarta (Tangerang and Serang). The hatchlings were then raised in the ranch for 3-4 years (Ratnawati, 2012) and then harvested (Figure 4b).

Crocodile skin sourced from the wild and from ranching were being traded domestically and internationally. The shipping point for international skin trade as Medan and Jakarta (Figure 4a). The skins for export were tagged for easier tracking. However, the tag must be taken off during tanning since it may compromise the tanning process. The skin will be retagged once the tanning process is completed.

\subsection{International Trade}

\subsubsection{The position of Indonesian Export in International Trade}

Based on Indonesia's crocodile export data from 2010 - 2017, the commodity being traded was skin, skin-based goods, meat, back croc bone, oil, and crocodile's genitals, with the skin being the dominating commodity (Figure $7 \mathrm{~b}$ and $\mathrm{c}$ ). Likewise, the international trade was also dominated by crocodile skin from species such as the American alligator from the United States, the Nile crocodile from South Africa, brown caiman from Columbia, yacare from Bolivia, Brazil and Paraguay, $C$. porosus from Australia, Papua New Guinea, and Indonesia, and C. novaeguineae from Indonesia and Papua New Guinea (Caldwell, 2017). The comparison between C. porosus' and C. novaeguineae's trade and the world's crocodile skin trade from the order of Crocodylia in $2014-2017$ is seen in Figure 5 below.

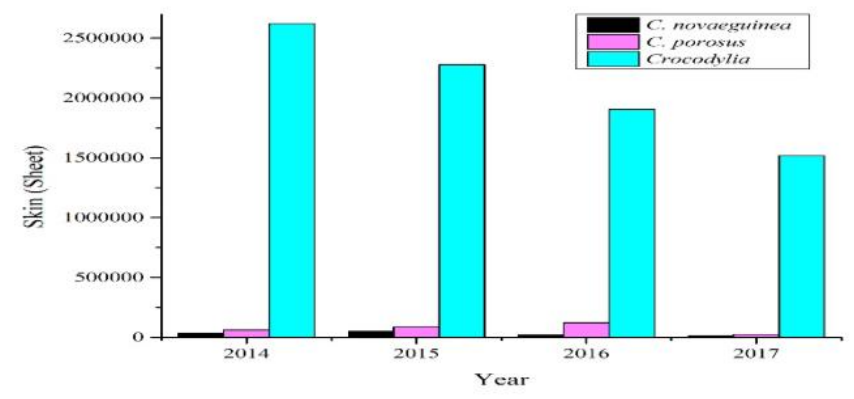

Figure 5. The position of $C$. Porosus and $C$. novaeguineae trade compared to all Crocodylia order trade from 2014-2017

The world's crocodile skin trade, in general, was declining in $2014-2017$, which was started in 2014 (Caldwell, 2017; CITES, 2019). C. porosus' and C. novaeguineae's trade also declined but did not begin until 2016 - 2017. In the international trade, C. porosus skin comes from Australia, Bangladesh, Indonesia, Papua New Guinea, Philippines, Singapore, and Thailand, while $C$. novaeguineae skin comes from Indonesia and Papua New Guinea (Caldwell, 2017; CITES, 2019). The crocodile supply from those countries can be seen in Figure 6 . 

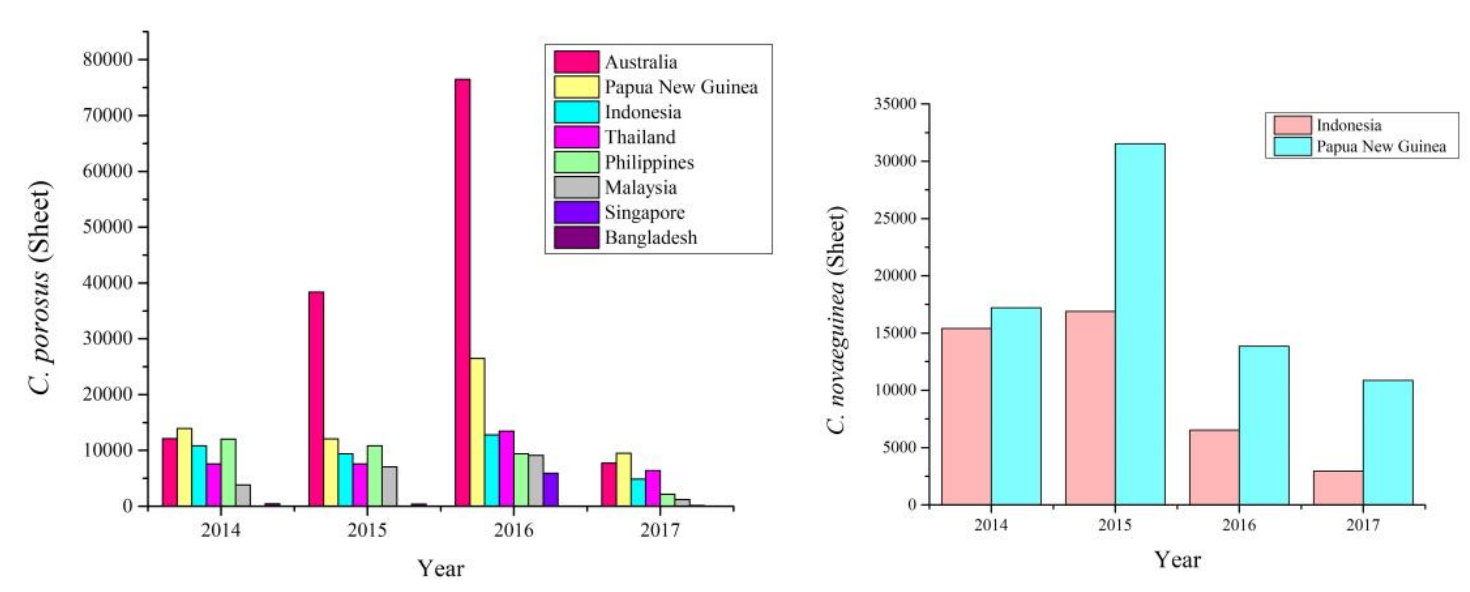

Source: The crocodile trade annual report data (CITES, 2019), processed by authors

Figure 6. The supply for $C$. porosus and $C$. novaeguineae from various countries in the world's market

The supply for $C$. porosus was dominated by Australia, Papua New Guinea, Thailand, and Indonesia. In 2014 - 2017, Indonesia was always in the fourth place for the world's largest $C$. porosus skin exporter after Australia, Papua New Guinea, and Thailand; except for 2016 where Philippines was the third largest exporter. Crocodile export from those countries mainly sourced from the wild, ranching, and captive breeding. However, $C$. porosus from Malaysia, Philippines, Thailand and Bangladesh all were sourced from captive breeding that were registered in CITES Secretariat, since $C$. porosus there was listed in Appendix I.

C. porosus exported from Indonesia was sourced from ranching and captive breeding, while sourcing from the wild has been banned since 2006 based on the recommendation from Scientific Authority in 2005 (Kurniati, 2016; Caldwell, 2017). Different cases applied in Australia and Papua New Guinea. All export from Papua New Guinea was sourced from the wild, while Australia had a small portion of its export sourced from the wild (CITES, 2019).

The export of $C$. novaeguineae from Indonesia was always lower than Papua New Guinea. The export from Papua New Guinea was sourced from the wild since 2004 (Caldwell, 2017), while Indonesia's export came from ranching and sourced from the wild.

\subsubsection{Export commodity}

The species from Indonesia traded for its skin are C. porosus and C. novaeguineae. The skin was exported in the forms of wet blue, crusted, finished, and final goods. The final goods exported were watch straps, handbags, passport case, name card holder, coin pouch, belts, key holders, lipstick case, mobile phone case, bracelets, necklaces, earrings, and shoes.

The export of $C$. porosus and $C$. novaeguineae skin fluctuated in 2010-2017 (Figure 7a). The export of $C$. novaeguineae reached its peak in 2015 , while $C$. porosus reached its peak in 2014 . In 2010, the export of $C$. porosus was higher than $C$. novaeguineae, and the opposite happened from 2011-2015. The situation then flipped back again in 2016-2017, where $C$. porosus export is back higher than C. novaeguineae.

C. porosus exported from Indonesia was sourced from ranching and captive breeding. From 2010-2017, the export source was dominated by captive breeding, which was ranging between 
76.79-94.99\% (Figure 7c.). The major C. porosus export commodity was skin, which covered between $97.53-99.75 \%$ of the total export, and the rest was final goods (Figure 7c).

The Export commodity from $C$. novaeguineae species was sourced from the wild and ranching. Business actors did not do captive breeding for this species, and thus there was no export from that source. Most of the species' commodity was sourced from the wild, ranging from $81.06-98.61 \%$ (Figure $7 \mathrm{~b}$ ). The main product exported was the skin that ranged between $76.50-99.62 \%$ of the total export.
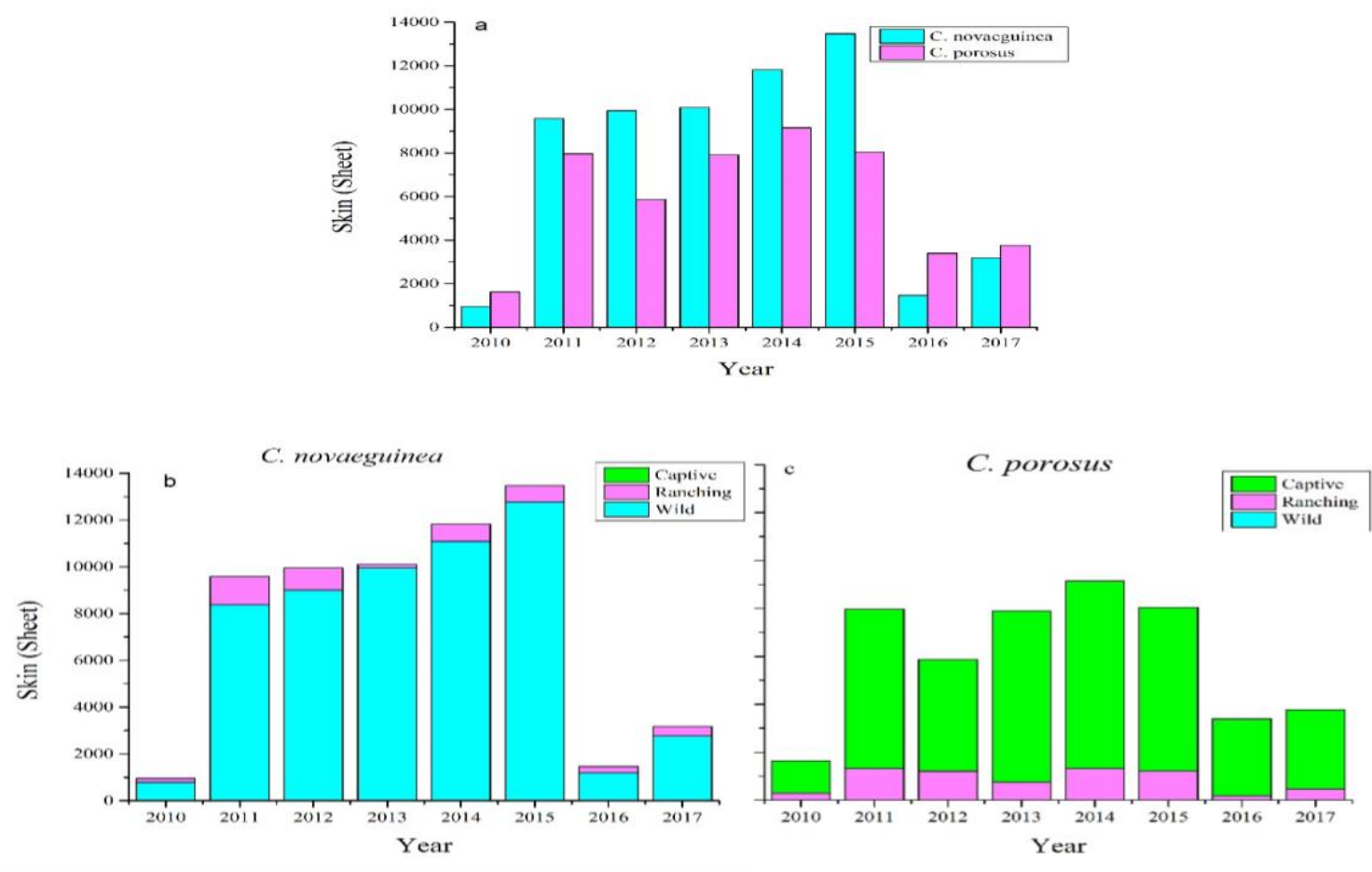

Figure 7. Indonesia's crocodile export: C. novaeguineae vs. C. porosus (a), and wild vs. ranching vs. captive (b dan c).

Crocodile skin from Indonesia is mostly exported to Hong Kong, Japan, and Singapore. Other countries that import crocodile skin from Indonesia, among others, are Italy, China, France, Saudi Arabia, Korea, and Turkey (Figure 8).

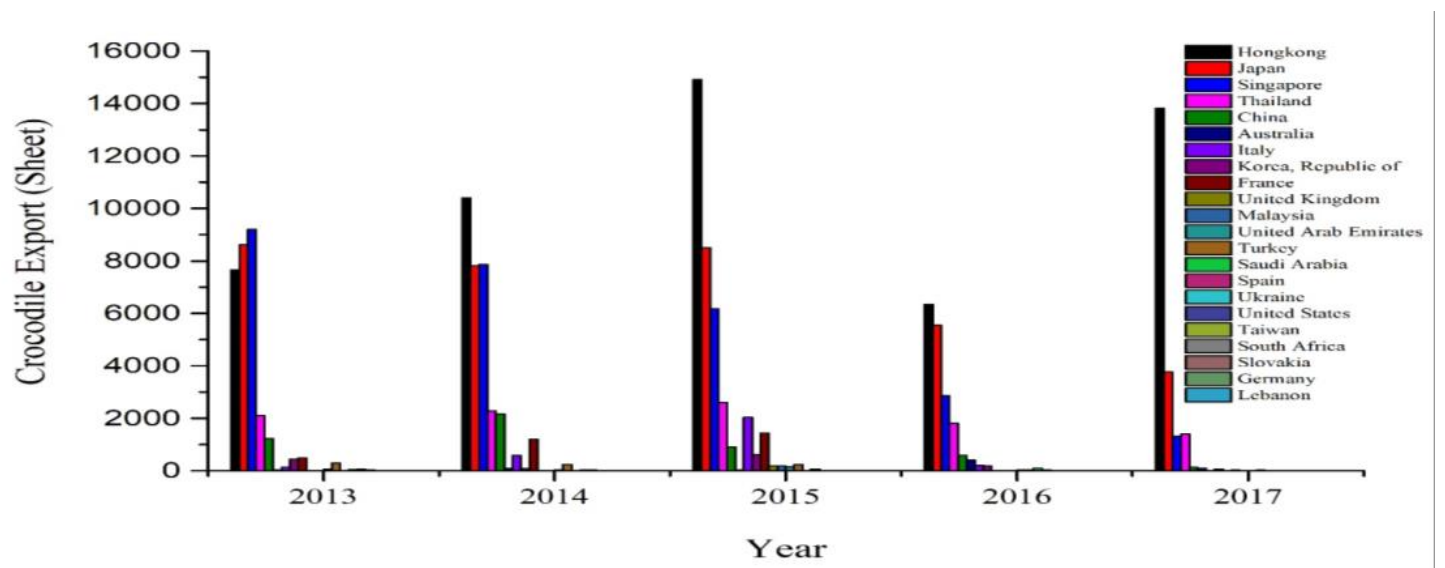

Figure 8. The number of $C$. porosus and C. novaeguineae export from 2013-2016 based on country of destination 


\section{Discussion}

Wildlife trade for export will only be granted if the scientific authority recommended a nondetriment finding (NDF), ensuring that the export will not detriment the survival of the traded species (Resolution Conf. 16.7). NDF is based on a comprehensive review of all available information, such as species biology and life-history characteristics; species range; population structure, status, and trends (in the harvested area, nationally and internationally); threats; historical and current species-specific levels and patterns of harvest and mortality; management measures currently in place and proposed, including adaptive management strategies and consideration of levels of compliance; population monitoring; and conservation status.

To guarantee that the crocodile export will not harm species survival in the wild, the Management Authority has made various efforts. The efforts include periodic monitoring of crocodile population in the hunting area (BBKSDA Papua, 2015a; BBKSDA Papua, 2015b; BBKSDA Papua Barat, 2015; BBKSDA Papua, 2016; BBKSDA Papua, 2017; Kurniati et al., 1999; Kurniati, 2002; Kurniati et al., 2017), set quotas for crocodile hatchlings (Figure $3 \mathrm{e}, \mathrm{f}, \mathrm{g}, \mathrm{h}$ ), and harvest quotas for skin (Figure $3 a, b, c, d$ ), set export quota based on the recommendation from Scientific Authority, and develop a traceability system (UNCTAD, 2014; Yao \& Zhu, 2019).

The quota set for crocodile hunting was relatively unchanged (Figure 3 ) due to the limited data of the wild population. This limitation was caused by the inability to conduct a continuous and comprehensive population monitoring in the hunting area. The limitation could be minimized by doing research collaboration between scientists, scientific authority, management authority, and the local community (Smith et al., 2011). Population monitoring was conducted in the hunting areas in Memberamo (BBKSDA Papua, 2015a; BBKSDA Papua, 2016; Kurniati, 2002; Kurniati et al., 2017), Merauke (BBKSDA Papua, 2015b; BBKSDA Papua, 2017), and Bird's Head zones (BBKSDA Papua Barat, 2015; Kurniati et al., 1999; Kurniati, 2016), but in different and changing locations. However, since 2015, population monitoring was done periodically in a permanent area in the up, middle, and downstream area of Memberamo Zone every year, and every two years in Merauke Zone.

To implement the Resolution Conf. 315 now Resolution Conf. 11.16, Scientific Authority recommended a zero harvest quota for $C$. porosus skin since 2005 (Kurniati, 2016). However, the Management Authority set a harvest quota for C. porosus skin in 2013 and 2014 (Figure 3 c, d). The quota set was considered a mistake by the management authority and scientific authority. Therefore the quota that has already been given was used for domestic trade, while the export remained zero. The zero commitment was to keep Indonesia's commitment as stated by the Government of Indonesia in the Annual Report on Ranching Operation of the saltwater Crocodile $C$. porosus (2006-2015) in 2016 (Kurniati, 2016). Furthermore, the tracking of domestic transport permit data suggested that there was no delivery of $C$. porosus skin from Tanah Papua for export purposes within that period.

In 2015, the head of Papua NRCO granted harvest quota for $C$. porosus skin to the craftsmen (Table 1). However, in that same year, the hunting of $C$. porosus did not appear in the national quota for Papua Province (Figure 3c). The quota setting was contradictory to the national quota though there was no realization. The quota set by the head of NRCO was, in fact, an indication of market demand for $C$. porosus supply sourced from the wild. The demand was observed from the supply of $C$. porosus sourced from the wild to the craftsmen in Merauke in 2017, which was $25 \%$ of the total number of $C$. porosus and $C$. novaeguineae.

The policy to ban the harvest quota of $C$. porosus could not stop $C$. porosus supply from the hunters. There was precedent for a similar case with other species in the world. Setting zero quota 
for export could not stop the demand and supply of Javan pangolin commodities in East and Southeast Asia (Challender et al., 2015). The same pattern also happened to the total ban of South American camelid (Vicugna vicugna) in international trade, which did not stop the hunting of the species (Mcallister et al., 2009).

Granting the harvest quota of $C$. porosus in 2013 and 2014 was a pro-people policy and was meant for the community who depend on their livelihoods as crocodile hunters. In this case, the hunting of $C$. porosus by the community was legal. On the other hand, the hunting of $C$. porosus was illegal when the hunting quota was zero. The use of $C$. porosus skin, which was not included in the quota, could not be justified by regulations (Challender et. al, 2015), though it was not used for export purposes. If enforced, the community will commit a crime for hunting $C$. porosus. However, the government could not just ban the hunting of $C$. porosus by enforcing the law (Challender et al., 2015) without providing a solution in the form of alternative livelihood (Challender \& MacMillan, 2014; Epanda et al., 2019).

Regulating the utilization of crocodile should take into account potential impacts on the livelihoods of the poor (Resolution Conf. 8.3), which is the hunting communities living around the habitat of $C$. porosus (BBKSDA Papua Barat, 2015; BBKSDA Papua 2015b; BBKSDA Papua, 2017: Crocodile Specialist Group, 1996; Kurniati, 1999; Webb et al., 2010;), whose livelihoods depend on crocodile hunting activity (BBKSDA Papua, 2015a; Epanda, 2019; Oduor, 2020). Not making the communities become illegal hunters was also the reason behind Resolution Conf. 8.3 that said,"...legal trade in a species should not lead to increases in illegal trade anywhere in its range."

Setting the quota for crocodile hunting, mainly $C$. porosus should not be solely based on the implementation of Resolution Conf. 315 now Resolution Conf. 11.16 alone, which arranges the utilization of $C$. porosus from Indonesia for export purpose only sourced from ranching. It should also take into account the interests of the communities living (Curtin \& Keatinge, 2018) around the habitat of $C$. porosus (BBKSDA Papua Barat, 2015; BBKSDA Papua, 2015b; BBKSDA Papua, 2017; Crocodile Specialist Group, 1996; Kurniati, 1999; Webb et al., 2010;). The arrangement in Resolution Conf. 315 now Resolution Conf. 11.16 is for export purposes, so exceptions could be made for domestic use. To ensure that the species is utilized sustainably, the harvest quota for $C$. porosus could be set with supervision, and hunting is allowed only for adult crocodiles as it is set for the caiman in Venezuela (Velasco et al., 2003). The harvesting of a caiman from the wild does not cause a decrease in its population.

Most of $C$. novaeguineae exported was sourced from the wild, some from ranching, and none from captive breeding (Figure 7b). However, one of the ranchers in Banten has been successful in breeding $C$. novaeguineae in captivity (interview with ranch owner). Different from $C$. novaeguineae, the export of $C$. porosus was dominated by those from captive breeding, some from ranching, and none from the wild (Figure 7c).

The export sourced from ranching was low for both species (Figure $7 \mathrm{~b}, \mathrm{c}$ ). The figure was also low for hatchlings sourced from the wild for ranching (Figure $3 \mathrm{e}, \mathrm{f}, \mathrm{g}$, and $\mathrm{h}$ ). There was a significant difference between the data of $C$. porosus hatchlings hunting realization in $2013-2015$ (Figure 3g, h) and the data in the annual report on ranching operation of saltwater crocodile $C$. porosus submitted by the Republic of Indonesia to CITES Secretariat (Kurniati, 2016). This difference may be caused by the hunting realization data that was reported was actually the realization of delivery using the domestic transport permit document and not the actual hunting data. Therefore, the harvest showed in Figure $3 \mathrm{~g}$ and $\mathrm{h}$ were not the actual trend. As were not Figure $3 \mathrm{~b}$ and $\mathrm{c}$, since C. porosus harvest for its skin still took place but zero data was reported.

The legal international trade for crocodiles was well documented in the CITES database, and the countries of origin, exporters, importers, species, and the amount traded could be easily traced. However, domestic trade was less documented and not yet connected between regions in Indonesia. The distribution data was not integrated between NRCO that is in charge of trade in the region. The tracking of the species' origin in-country was conducted manually by using the domestic 
transport permit document. Moreover, the harvest data shown in Figure $3 \mathrm{c}, \mathrm{d}, \mathrm{g}$, and $\mathrm{h}$ did not reflect the actual condition in the field since recording was only done for crocodiles sent outside of the province. However, this did not give negative influence to the sustainability of crocodile utilization sourced from the wild as seen in the population monitoring report (BBKSDA Papua Barat, 2013a; BBKSDA Papua Barat, 2013b; BBKSDA Papua, 2014; BBKSDA Papua Barat, 2014; BBKSDA Papua, 2015a; BBKSDA Papua, 2015b; BBKSDA Papua Barat, 2015; BBKSDA Papua, 2016; BBKSDA Papua, 2017; Kurniati et al., 1999; Kurniati, 2002; Kurniati et al., 2017), which concluded that there were no population decline.

Indonesia provided a significant contribution to the world's crocodile trade, both $C$. porosus, and $C$. novaeguineae. The fact that most of $C$. porosus export was sourced from captive breeding and not from the wild was an achievement in ensuring the species' sustainable utilization. The achievement must be followed by traceability system (UNCTAD, 2014; Yao and Zhu, 2019), surveillance, and law enforcement to guarantee that the animals traded are indeed from captive breeding (Lyons \& Natusch, 2015) and not laundering (Janssen \& Chng, 2017; Lyons \& Natusch, 2011; Nijman \& Shepherd, 2009; Nijman et al., 2012;). This is in line with the world's development, where the issue on the environment (McDonagh and Prothero, 2014) and sustainability (Brindley \& Oxborrow, 2013; Papadas et al., 2017; Pomering, 2017) become the main factor in product marketing. The utilization of crocodile should be back to its initial objective, which was to reduce the dependence of crocodile sourced from the wild through ranching and captive breeding. Therefore, the government must provide incentive (Cubbage et al., 2006; Fischer et al., 2007) for ranching and captive breeding activity development.

\section{Conclusion}

Domestic crocodile trade did not show the actual trade. The data of harvest realization did not reflect the real harvest in the field. The data available were from domestic transport permits based on those transported out from Papua and West Papua Provinces. This failed to record crocodile utilization within the province, suggesting that the actual harvest is bigger than the number reported. Nonetheless, based on the population monitoring, the harvest did not give negative impact for species sustainability in the wild. The policy to set zero quota of $C$. porosus skin could not stop its supply for the craftsmen in Papua. The supply will remain available since stopping community's livelihood in areas dominated by $C$. porosus is impossible. Therefore, the government needs to review the policy on zero quota of $C$. porosus' skin sourced from the wild.

The export of $C$. porosus skin from Indonesia from 2010 - 2017 was mostly sourced from captive breeding, while $C$. novaeguineae was mostly sourced from the wild. Export sourced from ranching for the two species was very low, and so was the hatchling harvest for ranching purposes. The low number of export from, and hatchlings for ranching showed the low interest of business actors to operate ranching activity. Therefore, the government needs to increase ranching activity by setting up a regulation that incentivize ranching activities.

Acknowledgments: The authors would like to thank anonymous reviewers for their constructive feedback on earlier versions of this manuscript. The authors also thank all people that helped obtaining pattern and trend data on crocodile trade.

Conflicts of Interest: I affirm that authors have no conflict of interest within the article. I affirm that the founding sponsors had no role in the design of the study; in the collection, analysis, or interpretation of data; in the writing of the manuscript, and in the decision to publish the results.

\section{References}

Auliya, M. (2010). Conservation Status and Impact of Trade on the Oriental Rat Snake Ptyas mucosa in Java, Indonesia. Petaling Jaya, Selangor (MY). TRAFFIC Southeast Asia. 
Auliya, M., Altherr, S., Ariano-Sanchez, D., Baard, E.H., Brown, C., Brown, R.M., Cantu, J.C., Gentile, G., Gildenhuys, P., Henningheim, E., Hintzmann, J., Kanari, K., Krvavac, M., Lettink, M., Lippert, J., Luiselli, L., Nilson, G., Nguyen, T.Q., Nijman, V., Parham, J.F., Pasachnik, S.A., Pedrono, M., Rauhaus, A., Córdova, D.R., Sanchez, M.E., Schepp, U., van Schingen, M., Schneeweiss, N., Segniagbeto, G.H., Somaweera, R., Sy, E.Y., Türkozan, O., Vinke, S., Vinke, T., Vyas, R., Williamson, S., \& Ziegler, T.(2016). Trade in live reptiles, its impact on wild populations, and the role of the European market. Biological Conservation, 204, 103-119. doi: https://doi.org/10.1016/j.biocon.2016.05.017

BBKSDA Papua. (2015a). Inventarisasi dan Monitoring Populasi Buaya Irian Zona Mamberamo Hilir. BBKSDA Papua. (2015b). Monitoring Populasi Buaya di Zona Merauke (Komolom-Dolok).

BBKSDA Papua. (2016). Survei Monitoring Populasi Buaya di Zona Mamberamo Bagian Tengah (Dabra-Rouffaer).

BBKSDA Papua. (2017). Monitoring Spesies Buaya Irian Zona Merauke.BBKSDA Papua Barat. (2015). Laporan Kegiatan Monitoring Populasi Buaya di Kabupaten Sorong Selatan.

Brindley, C., \& Oxborrow L. (2013). Aligning the sustainable supply chain to green marketing needs: A case study. Industrial Marketing Management. doi: https://doi.org/10.1016/j.indmarman.2013.08.003

Caldwell, J. (2015). World trade in crocodilian skins 2011-2013. UNEP-WCMC, Cambridge.

Caldwell, J. (2017). World Trade in Crocodilian Skins 2013-2015. UNEP-WCMC. Cambridge.

Carpenter A., Andreone F., Moore R.D., Griffiths R. (2014). A review of international trade in amphibians: The types, levels and dynamics of trade in CITES-listed species. Oryx, 48, 565-574. doi: https://doi.org/10.1017/\$0030605312001627

Challender D.W.S., \& MacMillan DC. (2014). Poaching is more than an enforcement problem. Conservation Letters, 7 (5), 484-494. doi: https://doi.org/10.1111/conl.12082

Challender, D.W.S., Harrop, S.R., \& MacMillan, D.C. (2015). Understanding market to conserve trade-threatened species in CITES. Biological Conservation, 187, 249-259. doi: https://doi.org/10.1016/j.biocon.2015.04.015

CITES. (2017). CITES trade database. Retrieved from: https://trade.cites.org/en/cites_trade/

Cox, J.H. (2010). New Guinea Freshwater Crocodile Crocodylus novaeguineae. Pp. 90-93 in Crocodiles. Status Survey and Conservation Action Plan. Third Edition, ed. by S.C. Manolis and C. Stevenson. Crocodile Specialist Group: Darwin.

Crocodile Specialist Group. (1996). Crocodylus porosus. The IUCN Red List of Threatened Species 1996: e.T5668A11503588.

doi: https://doi.org/10.2305/IUCN.UK.1996.RLTS.T5668A11503588.en.

Cubbage F., Harou P., \& Sills E. (2006). Policy instruments to enhance multi-functional forest management. Forest Policy and Economics 9 (2007) 833-851. doi: https://doi.org/10.1016/j.forpol.2006.03.010

Curtin, R., \& Keatinge, M. (2018). A methodology to measure the social impact of the EU quota setting procedure. Marine Policy, 95, 248-255. doi: https://doi.org/10.1016/j.marpol.2018.05.023

D'Cruze, N., \& Macdonald, D.W., (2015). Clouded in mystery: The global trade in clouded Leopards. Biodiversity and Conservation, 24 (14), 3505-3526. https://doi.org/10.1007/s10531-015-10109

Departemen Kehutanan. (2003). Keputusan Menteri Kehutanan Nomor 447/Kpts-II/2003 tentang Tata Usaha Pengambilan atau Penangkapan dan Peredaran Tumbuhan dan Satwa Liar.

Epanda, M. A., Mukam Fotsing, A. J., Bacha, T., Frynta, D., Lens, L., Tchouamo, I. R., \& Jef, D. (2019). Linking local people's perception of wildlife and conservation to livelihood and poaching alleviation: A case study of the Dja biosphere reserve, Cameroon. Acta Oecologica, 97, 42-48. doi: https://doi.org/10.1016/j.actao.2019.04.006 
Fischer, A., Petersen, L., Feldkotter, C., \& Huppert, W. (2007). Sustainable governance natural resources and institutional cahnge-an analytical framework. Public administration and development 27, 123-137. doi: https://doi.org/10.1002/pad.442

Grieser-Johns A., \& Thomson J. (2005). Going, Going, Gone: The Illegal Trade in Wildlife in EAST and Southeast Asia. World Bank, Washington, DC.

Harfoot, M., Glaser, A.M., Tittensor, D.P., Britten, G.L., Malsch, K., \& Burgess, N.D. (2018). Unveiling the patterns and trends in 40 years of global trade in CITES-listed wildlife. Biological Conservation, 223, 47-57. doi: https://doi.org/10.1016/j.biocon.2018.04.017

Janssen, J., \& Chng, S.C.L. (2017). Biological parameters used in setting captive-breeding quotas for Indonesia's breeding facilities. Conservation Biology, 32 (1), 18-25. doi: https://doi.org/10.1111/cobi.12978

KLHK. (2018). Peraturan Menteri Lingkungan Hidup dan Kehutanan Nomor P.20/MENLHK/SETJEN/KUM.1/6/2018 tentang Jenis Tumbuhan dan Satwa yang Dilindungi junto Peraturan Menteri Lingkungan Hidup dan Kehutanan Nomor P.92/MENLHK/SETJEN/KUM.1/8/2018.

http://jdih.menlhk.co.id/index.php/permenlhk/search

Kurniati, H., Rumbarar, Y., Mumpuni, \& Semiadi, G. (1999). Status Populasi Buaya (Crocodylus porosus) di Daerah Kaimana dan Teluk Arguni, Irian Jaya. Jurnal Zoo Indonesia 2002(29).

Kurniati, H. (2002). Spotlight survey of New Guinea Freshwater Crocodile (Crocodylus novaeguineae) in Mid-Zone Membramo River (Membramo and Rouffaer River System), Papua Province).

Kurniati, H. (2016). Annual Report on Ranching Operation of the Saltwater Crocodile Crocodylus porosus (2006-2015) [Submitted by the Republic of Indonesia to CITES Secretariat]. doi: https://doi.org/10.13140/RG.2.1.4076.3124

Kuniati, H., Nugroho, A., \& Wiradinata, E.M. (2017). Review of Crocodylus novaeguineae from Indonesia (submitted by the Republic of Indonesia to Species Programme-UN Environment World Conservation Monitoring Centre). Jurnal Berkala Penelitian Hayati, 4, 51-60.

Lyons, A. \& Natusch, D.J.D. (2011). Wildlife laundering through breeding farms: Illegal harvest, population declines and a means of regulating the trade of green pythons (Morelia viridis) from Indonesia. Biological Conservation, 144, 3073-3081. doi: https://doi.org/10.1016/j.biocon.2011.10.002

Lyons, J., \& Natusch, D., (2015). Methodologies for Differentiating between Wild and Captive-bred CITES-Listed Snakes. Gland, Switzerland.

Mcallister, R.R.J., Mcneill, D., \& Gordon, I.J. (2009). Legalising markets and the consequences for poaching of wildlife species: a test using the vicuña as a case study. J. Environ. 90, 120-130. doi: https://doi.org/10.1016/j.jenvman.2007.08.014

McDonagh, P., \& Prothero, A. (2014). Sustainability marketing research: Past, present and future. Journal of Marketing Management, 30(11-12), 1186-1219. doi: https://doi.org/10.1080/0267257X.2014.943263

Natusch, D.J.D., Lyons, J.A., Mumpuni, Riyanto, A, Khadiejah, S., Mustapha, N., Badiah, \& Ratnaningsih, S. (2016). Sustainable management of the trade in reticulated python skins in Indonesia and Malaysia. A report under the 'python conservation partnership' programme of research. Occasional paper of the IUCN Species Survival Commission No. 61. Gland, Switzerland: IUCN. 46pp. doi: https://doi.org/10.2305/IUCN.CH.2016.SSC-OP.61.en

Nijman, V., \& Shepherd, C.R. (2009). Wildlife Trade from ASEAN to the EU: Issues with the Trade in Captive-bred Reptiles from Indonesia. TRAFFIC Europe Report for the European Commission, Brussels, Belgium.

Nijman, V. (2010). An overview of international wildlife trade from southeast asia. Biodiversity and Conservation, 19, 1101-1114. doi: https://doi.org/10.1007/s!0531-009-9758-4 
Nijman, V., Shepherd, C.R., Mumpuni, \& Sanders, K.L. (2012). Over-exploitation and illegal trade of reptiles in Indonesia. Herpetological Journal, 22, 83-89.

Nurmalasari, E., Santosa, Y., \& Prihadi, N. (2016). Penentuan Kuota eksportir jenis kulit Sanca Batik (Python reticulatus Scheineder 1801) di Indonesia. Journal of Env. Engineering \& Waste Management, (1), 2, 64-74.

Oduor, A.M.O. (2020). Livelihood impacts and governance processes of community-based wildlife conservation in Maasai Mara ecosystem, Kenya. Journal of Environmental Management, 260, 110133. doi: https://doi.org/10.1016/j.jenvman.2020.110133

Pires, S.F., \& Moreto, W.D. (2011). Preventing wildlife crime: Solution that can overcome the 'tragedy of the commons'. Euro Journal of Criminal Policy Research, 17, 101-123. doi: https://doi.org/10.1007/s10610-011-9141-3

Papadas, K. K., Avlonitis, G. J., \& Carrigan, M. (2017). Green marketing orientation: Conceptualization, scale development and validation. Journal of Business Research, 80, 236246. doi: https://doi.org/10.1016/j.jbusres.2017.05.024

Pomering, A. 2017. Marketing for sustainability: Extending the conceptualisation of the marketing mix to drive value for individuals and society at large. Australasian Marketing Journal. doi: https://doi.org /10.1016/j.ausmj.2017.04.011

Ratnawati, L.D. (2012). Keberhasilan penangkaran buaya muara Crocodylus porosus Schneider, 1801 dengan pola pembesaran: Studi kasus penangkaran buaya di Provinsi Papua [Master's thesis, IPB University] doi: https:// https://repository.ipb.ac.id/handle/123456789/59535

Robinson, J.E., Griffiths, R.A., St. John, F.A.V., \& Roberts, D.L. (2015). Dynamics of the global trade in live reptiles: Shifting trends in production and consequences for sustainability. Biological Conservation, 184, 42-50. doi: https://doi.org/10.1016/j.biocon.2014.12.019

Robinson, J. E., \& Sinovas, P. (2018). Challenges of analyzing the global trade in CITES-listed wildlife. Conservation Biology. doi: https://doi.org/10.1111/cobi.13095

Sekretariat Negara. (1999). Peraturan Pemerintah Nomor 7 Tahun 1999 tentang Pengawetan Tumbuhan dan Satwa. https://jdih.setneg.go.id/Produk

Smith, M.J., Benitez-Diaz, H., Clemente-Munoz, M.A., Donaldson, J., Hutton, J.M., Noel McGough, H., Medellin, R.A., Morgan, D.H.W., O'Criodain, C., Oldfield, T.E.E., Schippmann U, Williams RJ. (2011). Assessing the impacts of international trade on CITES-listed species: Current practices and opportunities for scientific research. Biological Conservation 144, 82-91. doi: https://doi.org/10.1016/j.biocon.2010.10.018

Solmu, G. \& Manolis, C. (2019). Crocodylus novaeguineae. The IUCN Red List of Threatened Species 2019: $\quad$ e.T46591A3010398. doi: https://doi.org/10.2305/IUCN.UK.20192.RLTS.T46591A3010398.en

Sutherland, W.J., Adams, W.M., Aronson, R.B., Aveling, R., Blackburn, T.M., Broad, S., Ceballos, G., Côté, I.M., Cowling, R.M., \& Da Fonseca, G.A.B. (2009). One hundred questions of importance to the conservation of global biological diversity. Conservation Biology, 23 (3), 557-567. doi: https://doi.org/10.1111/j.1523-1739.2009.01212.x

UNCTAD. (2014). Traceability Systems for a Sustainable International Trade in South East Asian Phyton Skins. New York and Geneva. https://unctad.org/en/PublicationsLibrary/ditcted2013d6_en.pdf

Velasco, A., Colomine, G., De Sola, R., \& Villarroel, G. (2003). Effects of sustained harvest on wild populations of Caiman crocodilus crocodilus in Venezuela. Interciencia, 2 8(9), 544-548.

Webb, G.J.W., Manolis, S.C., \& Brien, M.L. (2010). Saltwater Crocodile Crocodylus porosus. Pp. 99113 in Crocodiles. Status Survey and Conservation Action Plan. Third Edition, ed. by S.C. Manolis and C. Stevenson. Crocodile Specialist Group: Darwin

Yao, S., \& Zhu, K. (2019). Combating product label misconduct: The role of traceability and market inspection. European Journal of Operational Research. doi: https://doi.org/10.1016/j.ejor.2019.09.031 